\title{
ANTHROPOLOGICAL ANALYSIS OF FIVE SKELETONS FROM SARMATIAN CULTURE DISCOVERED IN TIMIȘOARA - FREIDORF (ROMANIA)
}

\author{
Ștefan Popa ${ }^{1}$, Ionela Rădac ${ }^{1, *}$, Rodica Torok-Oance ${ }^{2}$ \\ ${ }^{1}$ National Museum of Banat, Archeology Department, Timișoara, Romania \\ ${ }^{2}$ West University of Timisoara, Faculty of Chemistry, Biology, Geography, Timișoara, Romania
}

\begin{abstract}
During a rescue excavation campaign in 2017, human osteological remains were discovered in the Timişoara - Freidorf archeological site, which based on funeral inventory were attributed to Sarmatian and Gepidic cultures. The main purpose of this paper is to perform an anthropological analysis of the 5 Sarmatian subjects discovered within this archaeological research. Specific morphological aspects were used to determine height, sex, age at death, non-metric traits, musculoskeletal markers or pathologies. It was determined that the subjects are 2 subadults and 3 adults at time of death: 1 male, 2 females and 2 with the sex undetermined due the immature age. Morphologic traits observed on these skeletons such as the septal aperture, Allen's fossa, hyperdorsiflexion facets, Schmorl's nodes, Allen's fossa and Charles'facet, may give a clue of the lifestyle and the intensity of physical activities from the Migration Period.
\end{abstract}

Keywords: epigenetic traits, Migration Period, musculoskeletal markers, non-metric traits, osteological pathologies.

\section{INTRODUCTION}

Sarmatians are migratory people of Iranian origin arriving in the Central Danubian Basin during the Migration Period and came from the North - Pontic region (Bârcă and Symonenko, 2009). Although the physical anthropological studies are on the rise in Romania, there are still a few publications on this population in the last decade (Oța and Comşa, 2012; Radu and Szeredai, 2014; Simalcsik, 2018). In Timiș County there are a few archaeological sites that have Sarmatian human remains. Many graves were found in Foieni (Grumeză, 2011) and Sânnicolau Mare (Bejan et al., 2011), but they were not anthropologically studied. A detailed analysis was made on a Sarmatian human skeleton discovered in Gelu (Gârleanu, 2015) and a study of dental anthropology, concerning malocclusions was made on a specimen from Timisoara - Freidorf site, found in 2017 (Beschiu et al., 2019). During a rescue excavation that took place in Timișoara - Freidorf site in 2017, a series of human osteological remains were discovered, dated back to the $4^{\text {th }}$ and $5^{\text {th }}$ century AD (Timoc et al., 2017). The archaeological research on this site started in 1982 with the first record of human osteological remains pointed out by Gh. Lazarovici, F. Resch and C. Ghermann. Although the remains were not liable to a cultural affiliation due to a lack of funeral inventory, a short osteological analysis was made on those bones (Lazarovici et al., 1983). The excavations continued in 1984, 1986 - 1993 and 1994 - 1998 with only the mention of Germanic graves dated from the 4th 
and 5th century AD (Mare, 2000). Gál (2011) made an anthropological analysis of 3 specimens that belong to hun - gepidic period excavated during a campaign that took place in 2006 and TorokOance et al. (2020) reported a rare co-occurrence of anatomical variations of the first cervical vertebra and the occipital in a Gepidic specimen with artificial cranial deformation excavated during 2017 campaign.

The purpose of this study is to perform a complex anthropological analysis of the Sarmatic human remains exhumed in 2017 from the archaeological site Timișoara - Freidorf (Timiș County from West Romania), including the state of the samples and the osteological inventory, estimating the height of individuals, the biological age, identification of the sex, the osteological pathologies, nonmetric traits and musculoskeletal markers.

\section{MATERIALS AND METHODS}

The analyzed osteological material was excavated from the archaeological site Timisoara - Freidorf (RAN code 155252.05) during the rescue excavation campaign from 2017, by a team of researchers from the National Museum of Banat. The archaeological site is situated in Timișoara (West of Romania), at the South edge of the city as a part of the Freidorf neighborhood.

The cultural affiliation of the analyzed subjects was determined by archaeologists based on the grave goods and the identification number of the subjects used in this paper is the same as the ones from the archaeological report (Timoc et al., 2017). The anthropological research started with the recording of the preservation level of the bones surface, rating from 1 to 5 according to Brickley and Mckinley (2004). The skeletal inventory and siding were recorded according to White and Folkens (2005) and the completeness score of the skeleton followed the methods of Buikstra and Ubelaker (1994).

Stature has been estimated using the line of organic correlation (Sjøvold, 1990). Sex determination was made using os coxae morphology (Phenice, 1969; Buikstra and Ubelaker, 1994; Canty et al., 2016) and cranial morphological traits (Buikstra and Ubelaker, 1994; White and Folkens, 2005).

Age at death was determined using aspects from the innominate bone (Todd, 1921; Lovejoy et al., 1985; Katz and Suchey, 1986; Brooks and Suchey, 1990; Buikstra and Ubelaker, 1994), wear and development of the dentition (White and Folkens, 2005), cranial sutures closure (Buikstra and Ubelaker, 1994; White and Folkens, 2005) and epiphyseal closure (White and Folkens, 2005).

Nonmetric traits, also known as discrete or epigenetic traits, were recorded using the methods of Singh (1959), Pandey and Singh (1990), Buikstra and Ubelaker (1994), Mann and collaborators (2016), Prasad and Rajasekhar (2018).

Identification of pathological conditions that leave traces on the bone was made according to Buikstra (2019) and Lovell (1997). Scoring entheseal changes were made using the standard method proposed by Mariotti et al. (2007) for 23 postcranial entheses.

\section{RESULTS AND DISCUSSIONS}

We identified 5 skeletons: 2 females, 1 male and 2 subadults with unidentified sex due to immature age. A detailed description was made for each individual, about the osteological inventory of the skeletons, osteological pathologies, epigenetic traits and entheses scoring.

In table 1 we present the preservation grade of bone surfaces, the level of completeness expressed as a percentage, taphonomic changes, stature, sex determination and estimation of biological age.

Among the most common observed taphonomic changes were erosions and exfoliation of the bones that can be influenced by the soil from the grave, age at death, grave distribution or heat (White et 


\section{Current Trends in Natural Sciences}

Vol. 9, Issue 18, pp. 20-31, 2020

https://doi.org/10.47068/ctns.2020.v9i18.003

Current Trends in Natural Sciences (on-line)

ISSN: 2284-953X

Current Trends in Natural Sciences (CD-Rom)

ISSN: 2284-9521

ISSN-L: 2284-9521

ISSN-L: 2284-9521

al., 2011). The majority of the fractures and fissures observed on this series of skeletons are post mortem and were produced by the excavation, transport and deposit process. Green stains on the bone that represent the effect of the metal objects interred with the analyzed remains, usually copper (Buikstra and Ubelaker, 1994), were recorded on subjects 155, 128 and 266.

Table 1. Summary of the anthropological findings for the studied samples

\begin{tabular}{|c|c|c|c|c|c|c|c|}
\hline ID & $\begin{array}{c}\text { Surface } \\
\text { preservation } \\
\text { (grade) }\end{array}$ & $\begin{array}{c}\text { Completeness } \\
(\%)\end{array}$ & $\begin{array}{c}\text { Taphonomic } \\
\text { changes }\end{array}$ & $\begin{array}{l}\text { Stature } \\
(\mathrm{cm})\end{array}$ & Sex & $\begin{array}{c}\text { Biological } \\
\text { Age }\end{array}$ & $\begin{array}{l}\text { Position } \\
\text { in situ }\end{array}$ \\
\hline 155 & 1 & $>75 \%$ & $\begin{array}{l}\text { erosion } \\
\text { green color }\end{array}$ & $\begin{array}{l}164.9 \pm \\
4.73\end{array}$ & q & $18-20$ & Supine - Fig. 1A \\
\hline 158 & 1 & $>75 \%$ & $\begin{array}{l}\text { erosion } \\
\text { fissures } \\
\text { green color }\end{array}$ & $\begin{array}{l}157.1 \pm \\
4.64\end{array}$ & 우 & $20-34$ & Supine - Fig. 2A \\
\hline 185 & 4 & $25-75 \%$ & erosion & - & - & $12-13$ & Supine - Fig. 3A \\
\hline 266 & 1 & $>75 \%$ & $\begin{array}{l}\text { erosion } \\
\text { exfoliation } \\
\text { green color }\end{array}$ & $\begin{array}{l}178.2 \pm \\
4.60\end{array}$ & 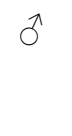 & $20-34$ & Supine - Fig. 4A \\
\hline 320 & 4 & $<25 \%$ & erosion & - & - & $5-7$ & Supine \\
\hline
\end{tabular}

\section{Individual no. 155}

Skeletal inventory (figure 1B). The skull is in good condition, all the bones are present except for the occipital bone which is represented by the basilar part and occipital condyles. Thoracic vertebra T11 and the coccyx are missing, the rest of the backbone is complete. Thoracic skeleton and shoulder girdle are poorly represented, the bones are incomplete or missing. Os coxae is poorly represented (less than $50 \%$ of the bone) but it has the greater sciatic notch presented on the right side and a fragment of the right auricular surface. All long bones were identified. Except for a proximal phalanx from the foot, the rest of the bones from hand and foot are missing. The dentition is complete.

Epigenetic traits (appendix I). Septal aperture (figure 1D), supraorbital notch, infraorbital suture, multiple zygomaticofaciale foramen ( 2 on the left side) and Allen's fossa (figure 1E). Septal aperture may permit hyperextension of the forearm and may be a predisposing factor to distal humerus fractures (Tubbs et al., 2016).

Osteological pathologies. Schmorl's nodes (figure 1C) are present on a considerable number of vertebrae (T6, T7, T8, T9, T10, T12, L1, L2, L3, S1) and may be indicative of trauma due to physical stress or the vertebral morphology (Lai and Lovell, 1992; Pfirrmann and Resnick, 2001; Plomp et al., 2015).

Entheses scoring (appendix II). Medium developed entheses are described on the clavicle (ligamentum trapezoideum, musculus pectoralis major, musculus deltoideus), humerus (musculus latissimus dorsi / teres major), ulna (musculus triceps brachii) and tibia (musculus soleus). A strong development is observable on ulna - musculus supinator. 


\section{Individual no. 158}

Skeletal inventory (figure 2B). The skull is fragmented post mortem and presents different degrees of taphonomic modifications, including green coloring (figure 2D) of some parts due to grave goods. Neurocranium is represented by the frontal, sphenoid, parietals, occipital (the basilar portion with occipital condyles) and temporals. Viscerocranium is lacking some elements, being represented by mandible, maxillae, zygomatic and vomer. The backbone is almost complete except for the coccyx bone. Thorax is fragmented and incomplete. Shoulder girdle is represented by complete clavicles and scapulas that are incomplete and fragmented. Os coxae is complete but with slight erosions and fragmentation. The long bones are all present, with some erosions at epiphysis. The small bones from the hands and foot are well preserved with a great part of them being recovered from the site. From the dentition are missing: $\mathrm{RI}_{2}, \mathrm{LC}_{1}, \mathrm{LM}_{3}$ (lost post mortem).

Epigenetic traits (appendix I). Although the skull is fragmented and some small parts are missing, 3 sutural bones have been identified (figure 2C). The shape of the articular surfaces of the talus for calcaneus is type B (right) and articular surfaces of calcaneus for talus (bilateral) is type B1.

Osteological pathologies. $\mathrm{LM}_{1}$ present caries in the mesial part of the crown. The incidence of caries in humans is influenced by their diet and sex. The occurrence is higher for females than males and that is regardless of the culture or chronological period (Lukacs and Largaespada, 2006). The lower incisive present dental calculus. The studied specimen presents hypodontia, missing $\mathrm{RI}^{2}$, $\mathrm{LI}^{2}, \mathrm{RI}_{2}, \mathrm{LI}_{2}$ and $\mathrm{LM}_{3}$. Hypodontia (figure $2 \mathrm{E}$ ) is a common dental developmental anomaly and genetically controlled in humans (Symons et al., 1993).

Entheses scoring (appendix II). The subject has a series of strongly developed entheses: clavicle conoid ligament, musculus deltoideus; humerus - musculus pectoralis major, all on the left side. It can also be observed a medium degree of entheses development on the rest of the skeleton except the foot. The deltoid and the pectoralis major muscles act together in movements like flexion and medial rotation of the arm, which are involved in lifting (Griffith, 2013).

\section{Individual no. 185}

Skeletal inventory (figure 3B). Frontal is fragmented and incomplete, from the occipital was recovered only one occipital condyle, parietals are poorly represented, temporals are fragmented with the mastoid process eroded, the left zygomatic, maxillae and mandibulae are fragmented and incomplete. All the vertebrae are missing. Clavicula is fragmented, the pelvic girdle is missing. The long bones present strong epiphyseal erosion; well preserved are the diaphysis of humerus, radius, femur and tibia. We identified an unfused distal epiphysis of the right femur and an unfused proximal epiphysis of the humerus.

The small bones of the hand and foot are poorly preserved. All the permanent teeth are erupted except for the $\mathrm{RM}_{3}, \mathrm{RM} 3$ and LM3 (figure 3C).

The poor preservation condition of the subject did not allow us to record epigenetic traits, osteological pathologies or to score the entheses.

\section{Individual no. 266}

Skeletal inventory (figure 4B). The frontal, occipital and parietal bones are complete but fragmented. The mandible is almost complete, with only one fragment from the left coronoid process missing. It is present the right zygomatic, the maxillary bone is incomplete and the rest of the viscerocranium is strongly fragmented. Dentition is almost complete, missing $\mathrm{RM}_{1}$ (intra-vitam) and $\mathrm{RI}^{2}$ (post-mortem). Innominate bone on the right side is fragmented with a greater sciatic notch and pubic symphysis intact, auricular surface fragmented but with the specific characters 


\section{Current Trends in Natural Sciences}

Vol. 9, Issue 18, pp. 20-31, 2020

https://doi.org/10.47068/ctns.2020.v9i18.003

Current Trends in Natural Sciences (on-line)

ISSN: 2284-953X

Current Trends in Natural Sciences (CD-Rom)

ISSN: 2284-9521

ISSN-L: 2284-9521

ISSN-L: 2284-9521

recognizable. The left side of the innominate bone is complete, with a slight erosion on the ischial tuberosity. The humerus, ulna, radius, femur and fibula are complete, presenting only slight erosion especially at epiphysis regions.

Epigenetic traits (appendix I). From the skull and postcranial skeleton, we identified: infraorbital foramina, incomplete closure of the transverse foramen from atlas, a double transverse foramen at sixth cervical vertebrae, squatting facets on distal tibia (figure 4E) and talus, and the presence of Charles facet (figure 4D) on distal femur. Articular surfaces of the talus corresponding to the calcaneus are type B1 and the calcaneus talar articular surfaces are type BI.

Osteological pathologies. The Schmorl's nodes (figure 4C) are observable at seven thoracic vertebrae and at the first lumbar vertebra. On the anterior part of the left femur inferior epiphysis and superior epiphysis of left tibia, were recorded peri mortem transverse marks.

Entheses scoring (appendix II). Strong development of the enthesis are recorded for clavicula conoid ligament, musculus pectoralis major and musculus deltoideus.

\section{Individual no. 320}

Skeletal inventory. The poorly represented skeleton allowed us to record just a few data regarding this individual. About half of the frontal bone was recovered, also fragments from parietals, occipital and mandible. There are small fragments of clavicle, ribs and vertebrae. The long bones are represented by diaphysis of the humerus (bilateral) and the middle part of the diaphysis of the left femur. The dentition recovered is represented by 7 decidual and 17 permanent teeth having different degrees of eruption.

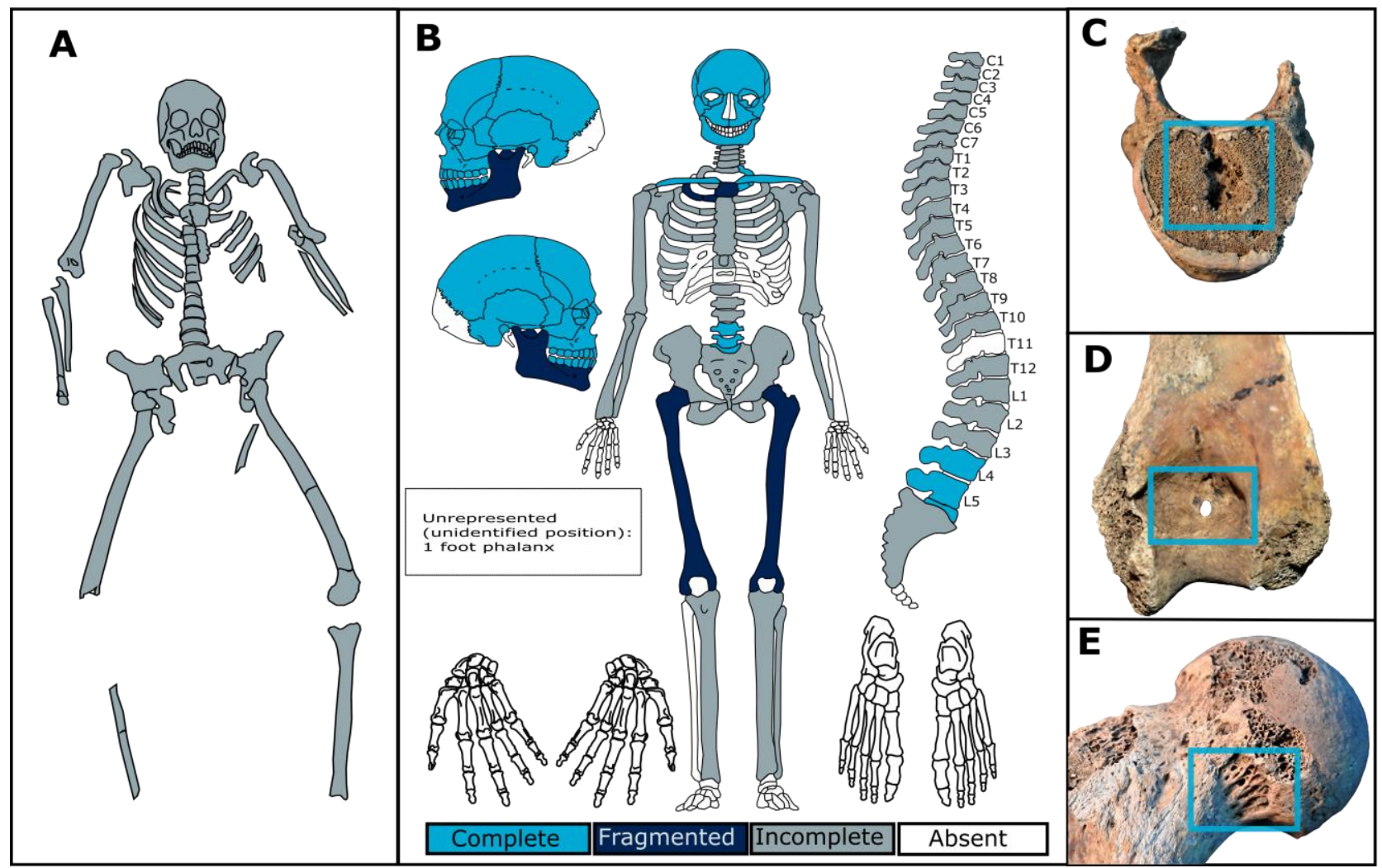

Figure 1. Individual no. 155: A - in situ, B-skeletal inventory, C-vertebrae with Schmorl's node, D-sepetal aperture on distal epiphysis from the right humerus, $E-$ Allen's fossa on the neck of the femur 


\section{Current Trends in Natural Sciences}

Vol. 9, Issue 18, pp. 20-31, 2020

https://doi.org/10.47068/ctns.2020.v9i18.003

Current Trends in Natural Sciences (on-line)

ISSN: 2284-953X

Current Trends in Natural Sciences (CD-Rom) ISSN-L: 2284-9521

ISSN: 2284-9521 ISSN-L: 2284-9521

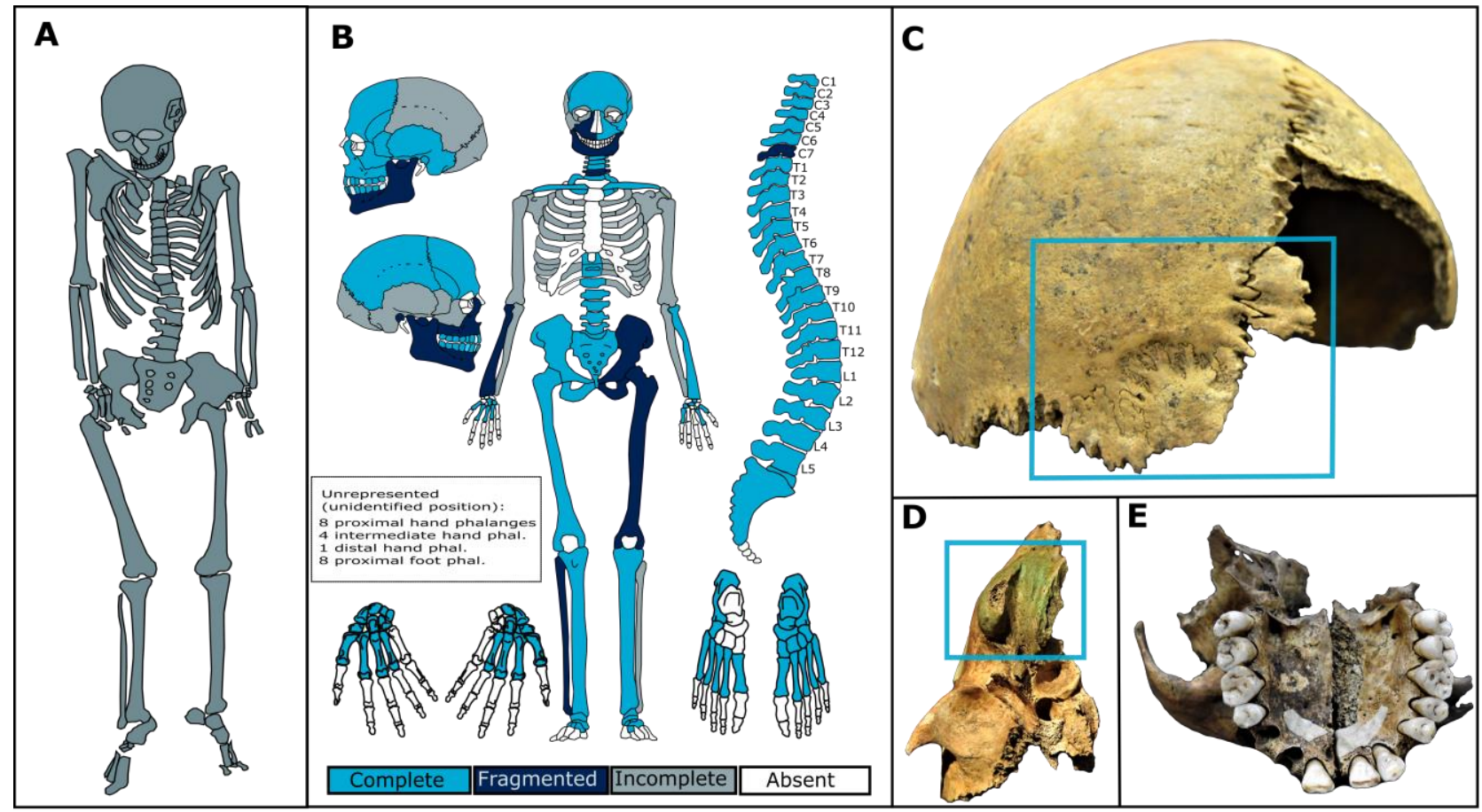

Figure 2. Individual no. 158: A - in situ, B-skeletal inventory, $C$-posterior view of the skull with sutural bones, $D$ - green coloring on the right mastoid process, $E$-inferior view of the maxillary presenting hypodontia

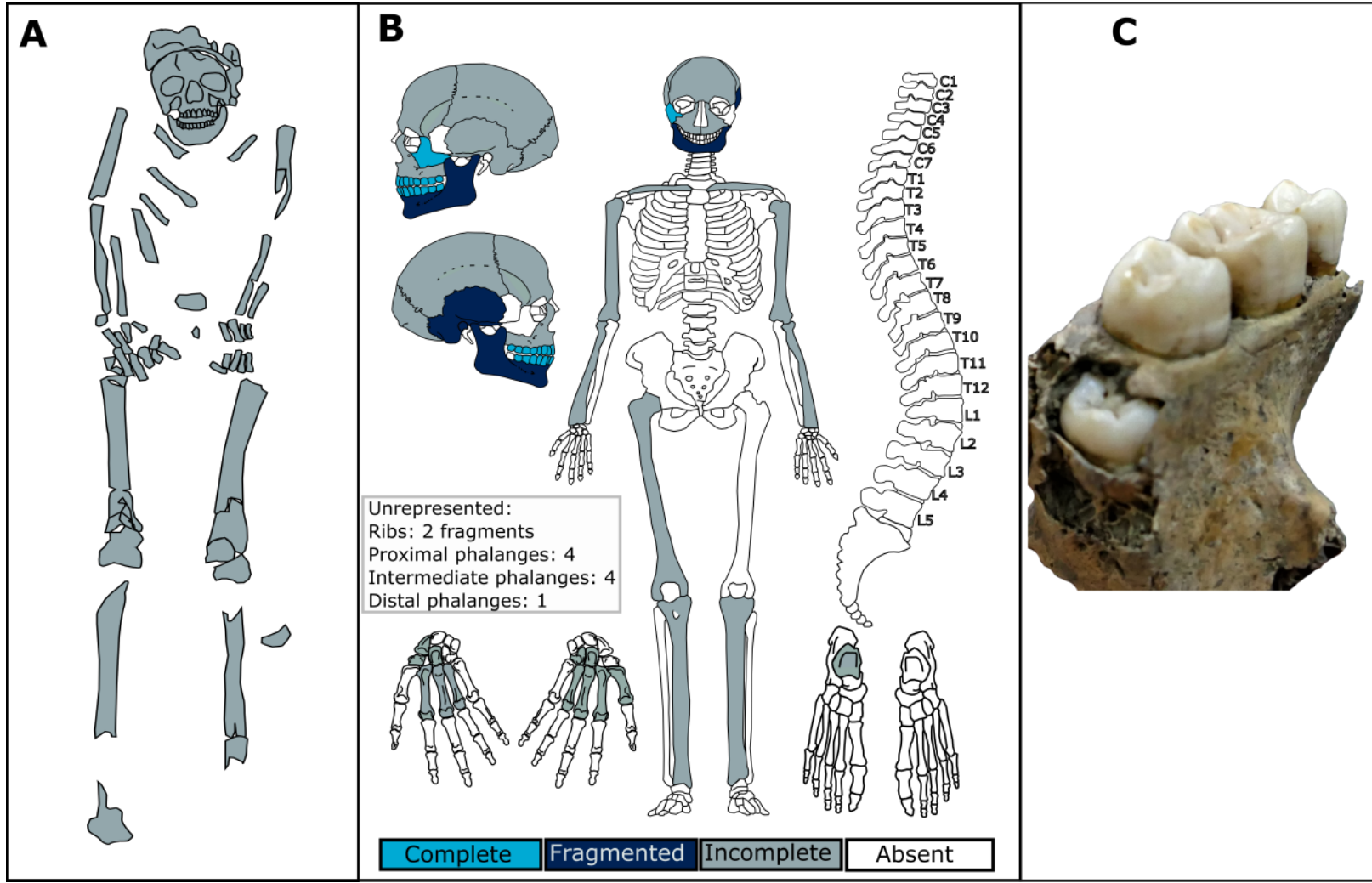

Figure 3. Individual no. 185: A - in situ, B - skeletal inventory, C-posterior view of the left maxilla 

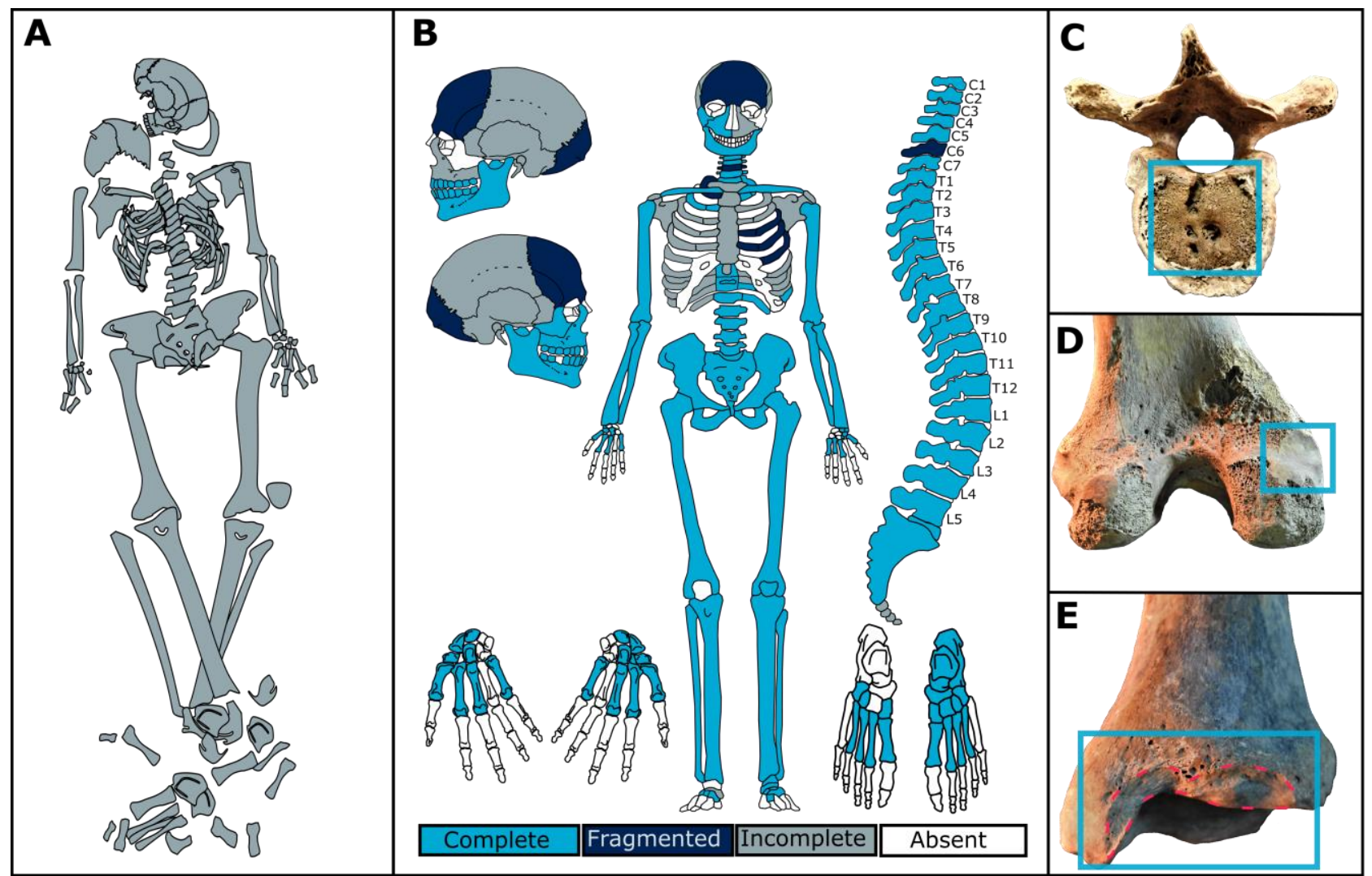

Figure 4. Indiviual no. 266: $A$ - in situ, $B$ - skeletal inventory, $C$ - Schmorl's nodes on a thoracic vertebra, D posterior view of the left femur with Charles facet, $E$ - squatting facets on distal epiphysis of the left tibia

\section{Non-metric traits and entheses}

The morphoscopic observations on the osteological remains from this study revealed a diverse series of non-metric traits, but the small number of analysed subjects does not allow a generalization to the Sarmatic population from this geographic region. Non - metric traits (also called epigenetic, discrete, or discontinuous morphological traits) represent small variations of the bone and teeth (White et al., 2011). The origin of each variation is debatable, with influence from environmental factors, genetic inheritance, sex, age, historical time and bilateral asymmetry (Corruccini, 1974; Trinkaus, 1978). Supraorbital notch was observed on the subject no. 158 and it appears to be influenced by the climatic condition being more common in individuals from warm climate areas (Tomaszwska, et al., 2012; Tomaszwska, et al., 2013). The presence and number of zygomatico-facial foramina varies among individuals and appears to be population specific (Aksu et al., 2009). In this study were observed at individual no. 1552 foramina on the left side.

Sutural (Wormian) bones could be found at the individual no. 158. The reason why Wormian bones form is unclear but it is believed that it may have environmental (including intentional cranial deformation), pathological or genetic influence (Bellary et al., 2013). Septal aperture formed on the distal humerus, was found on subject no. 155. The cause of this non-metric trait has been widely discussed with suggestions that its appearance is influenced by genetics, biomechanics of human movement, bone robusticity, osteoporosis and osteoarthritis (Myzska, 2015). Allen's fossa observed at subject no. 155, is a morphological change of the femur that appears at horse riders that may be related with a repeating hyperflexion of the hip (Anđelinović et al., 2015). According to some 
Vol. 9, Issue 18, pp. 20-31, 2020

https://doi.org/10.47068/ctns.2020.v9i18.003

studies it has an incidence that is age related (Finnegan, 1978; Stirland, 1996), other studies consider them in a category of epigenetic traits that are "induced by environmental factors and / or behavior" (Voisin and Condemi, 2013). The tibial and talar squatting facets that could be identified on subject no. 266, are connected to environment and behaviour (Voisin and Condemi, 2013) and they are a response of the hyper-dorsiflexion of the joints corresponding to the ankle and knee. Some studies suggest that squatting facets may be influenced by prolonged standings or longdistance walking on hard surfaces (Ari, 2003). Another feature present on the subject no. 266, which is in strong connection with the hyperdorsiflexion position is the Charles facet (Madhu et al., 2013).

The shape of articular surfaces of talus that corresponds to calcaneus and vice versa can be genetically induced but can also be influenced by differences in the gait and cultural habits (Bunning and Barnett, 1965). Also found in this study in two subjects (266 and 158) is type B of articular surfaces of calcaneus, which is the most common type found in populations of different genetic heritage (Boyan et al., 2016). Studies of various authors on incidence of the type of talus articular surfaces, show that type B is more common (Boyan et al., 2016). Our findings correspond to this, where it was possible to be recorded, talus surface is type B (B2 - 266, B1 - 158).

The study of entheses changes from human osteological remains, discovered in archaeological context, is a method to identify the intensity of possible daily physical activities of past populations (Molnar, 2006; Mariotti, 2007). The musculoskeletal markers that we recorded are not conclusive on the reconstruction of the past physical activities of the studied subjects, due to lack of complete skeletal surface preservation, in most cases. Where it was possible to record the entheses scoring, the high degrees are more common on the functional complex belonging to the shoulders, elbows and forearms of the studied subjects.

\section{CONCLUSIONS}

The information from the present study contributes to enriching the knowledge about Sarmatians, taking into account that there are only a few anthropological analysis of this population from the western part of Romania. Although it cannot be generalized to the entire population, this analysis reveals various indicators of stress experienced by members of the population, including several pathologies, both osseous and dental.

The Schmorl's nodes were observed on multiple vertebrae from two subjects. Additionally, in one case these nodes are associated with the septal aperture and Allen's fossa, other possible indicators of the various physical stressors experienced by the individual. The Allen's fossa appears in horse riders and it may give us a clue about a cultural custom of these ancient people. In another case, the nodes are associated with squatting facets and Charles facet, which correlated, can be an indicator for prolonged standings in a hyperdorsiflexed position or long-distance walking. Dental pathologies are represented by a small number of caries, hypodontia, dental calculus and one case of teeth lost ante-mortem.

Further studies are needed to better understand the lifestyle, diet and health problems of the Sarmatians.

\section{ACKNOWLEDGEMENTS}

The authors would like to thank to Dr. Călin Timoc (National Museum of Banat) for providing the human skeletal remains for study and for his support during the research. 


\section{REFERENCES}

Aksu, F., Ceri, N.G., Arman, C., Zeybek, F.G., Tetik, S. (2009). Location and incidence of the zygomaticofacial foramen: an anatomic study. Clin Anat, 22(5), 559-562.

Anđelinović, Š., Anterić, I., Škorić, E., Bašić, Ž. (2015). Skeleton changes induced by horse riding on medieval skeletal remains from Croatia. Int J Hist Sport, 32(5), 708-721.

Ari, I., Oygucu, I.H., Sendemir, E. (2003). The squatting facets on the tibia of Byzantine (13th) skeletons. Eur J Anat, 7(3), 143-146.

Bârcă, V., Symonenko, O. (2009). Călăreții stepelor, sarmații în spațiul nord pontic [Steppe riders, Sarmatians in the northern Pontic area]. Editura MEGA, 502 pp, Cluj Napoca. Romania.

Bejan, A., Măruia, L., Tănase, D. (2011). Un mormânt cu podoabe de aur din epoca sarmatică timpurie descoperit la Sânnicolaul Mare- Săliște (jud. Timiș) [A grave with gold ornaments from the early Sarmatian era discovered at Sânnicolaul Mare-Săliște (Timiș County)]. Analele Banatului SN 19, 161-180.

Bellary, S.S., Steinberg, A., Mirzayan, N., Shirak, M., Tubbs, R.S., Cohen-Gadol, A.A., Loukas, M. (2013). Wormian bones: a review. Clin Anat, 26(8), 922-927.

Beschiu, L. M., Rusu, L. C., Borlovan, M., David, O. T. (2019). Orthodontic status of a sarmatian man from the fourth century A.D. ARHEOVEST, VII, 737-745.

Boyan, N., Ozsahin, E., Kizilkanat, E., Soames, R., Oguz, O. (2016). Morphometric measurement and types of articular facets on the talus and calcaneus in an Anatolian population. Int J Morphol, 34(4), 1378 - 1385.

Brickley, M., McKinley, J.I. (2004). Guidelines to the Standards for Recording Human Remains. Institute of Field Archaeologists, BABAO, 62 pp, Southampton, Great Britain.

Brooks, S., Suchey, J.M. (1990). Skeletal age determination based on the os pubis: a comparison of the AcsádiNemeskéri and Suchey-Brooks methods. J Hum Evol, 5(3), 227-238.

Buikstra, J.E., Ubelaker, D.H. (1994). Standards for Data Collection from Human Skeletal Remains. Arkansas Archaeological Survey Research, 44, 206 pp, Arkansas, SUA.

Buikstra, J.E. (Ed.). (2019). Ortner's Identification of Pathological Conditions in Human Skeletal Remains. Academic Press, 839 pp, Phoenix, USA.

Bunning, P.S.C., Barnett, C.H. (1965). A comparison of adult and foetal talocalcaneal articulations. J Anat, 99(1), 7176.

Canty, E., Eliopoulos, C., Borrini, M. (2016). The preauricular sulcus and its link to sex and parturition: a test on a British Medieval collection. Am J Phys Anthropol, 159, 108, (conference poster).

Corruccini, R.S. (1974). An examination of the meaning of cranial discrete traits for human skeletal biological studies. Am J Phys Anthropol, 40(3), 425-445.

Finnegan, M. (1978). Non-metric variation of the infracranial skeleton. $J$ Anat, 125(1), 23.

Gál, S.S. (2011). Timişoara - Freidorf. Osteological analysis of human remains. MARISA, 31, 283 - 290.

Gârleanu, L. (2015). Cazul mormântului sarmatic de la Gelu: variație anatomică sau condiție patologică? [The case of the Sarmatian grave from Gelu: anatomical variation or pathological condition?]. Arheovest,3, 795-804.

Griffith, K., (2013). Musculoskeletal stress markers: a comparison between a 3D digitizing geometric morphometric approach and a more traditionalscoring method using clavicles from a $19_{\text {th }}$ century asylum collection from Pueblo, Colorado. Master's Thesis. Fort Collins: Colorado State University.

Grumeză, L. (2011). The samatian necropolis from Foieni (Timiș County), Analele Banatului SN, 19, 181-205.

Katz, D., Suchey, J.M. (1986). Age determination of the male os pubis. Am J Phys Anthropol, 69(4), 427-435.

Lazarovici, G., Resch, F., Ghermann, C. (1983). Descoperiri arheologice la Timişoara - Freidorf. [Archaeological discoveries at Timisoara - Freidorf]. Banatica, 7, 35 - 54.

Lovejoy, C.O., Meindl, R.S., Pryzbeck, T.R., Mensforth, R.P. (1985). Chronological metamorphosis of the auricular surface of the ilium: a new method for the determination of adult skeletal age at death. Am J Phys Anthropol, 68(1), 15-28.

Lai, P., Lovell, N.C. (1992). Skeletal markers of occupational stress in the fur trade: a case study from a Hudson's Bay Company fur trade post. Int J Osteoarchaeol, 2(3), 221-234.

Lovell, N.C. (1997). Trauma analysis in paleopathology. Am J Phys Anthropol, 104(S25), 139-170.

Lukacs, J.R., Largaespada, L.L. (2006). Explaining sex differences in dental caries prevalence: Saliva, hormones, and "life-history" etiologies. Am J Hum Biol, 18(4), 540-555.

Madhu, S., Suchismita, G., Neelam, V. (2013) Morphological traits at distal end of femur. World J Surg, 3(2), 20-25.

Mann, R.W., Hunt, D.R., Lozanoff, S. (2016). Photographic regional atlas of non-metric traits and anatomical variants in the human skeleton. Charles C Thomas Publisher.719 pp, Illinois, SUA. 
Vol. 9, Issue 18, pp. 20-31, 2020

https://doi.org/10.47068/ctns.2020.v9i18.003

Current Trends in Natural Sciences (on-line)

ISSN: 2284-953X

Current Trends in Natural Sciences (CD-Rom)

ISSN-L: 2284-952

ISSN: 2284-9521

ISSN-L: 2284-9521

Mare, M. (2000). Principalele rezultate ale cercetărilor arheologice efectuate la Timişoara-Freidorf între anii 19941998. [The main results of the archaeological campaigns from Timisoara - Freidorf (1994-1998)]. Analele Banatului SN, 7-8, 491-514.

Mariotti, V., Facchini, F., Belcastro, M.G. (2007). The study of entheses: proposal of a standardised scoring method for twenty-three entheses of the postcranial skeleton. Coll Antropol, 31(1), 291-313.

Molnar, P. (2006). Tracing prehistoric activities: musculoskeletal stress marker analysis of a Stone-Age population on the island of Gotland in the Baltic Sea. Am J Phys Anthropol, 129(1), 12-23.

Myszka, A. (2015). Septal aperture aetiology: still more questions than answers. Folia Morphol, 74(2), 219-224.

Oţa, L., Comşa, A. (2012). Un mormânt sarmatic descoperit la Călăraşi. [A Sarmatian grave found in Călăraşi]. Materiale şi cercetãri arheologice SN, 8, 97-106.

Pandey, S.K., Singh, S. (1990). Study of squatting facet/extension of talus in both sexes. Med Sci Law, 30(2), $159-164$.

Phenice, T.W. (1969). A newly developed visual method of sexing the os pubis. Am J Phys Anthropol, 30(2), $297-301$.

Pfirrmann, C.W., Resnick, D. (2001). Schmorl nodes of the thoracic and lumbar spine: radiographic-pathologic study of prevalence, characterization, and correlation with degenerative changes of 1,650 spinal levels in 100 cadavers. Radiology, 219(2), 368-374.

Plomp, K., Roberts, C., Strand Vidarsdottir, U. (2015). Does the correlation between schmorl's nodes and vertebral morphology extend into the lumbar spine? Am J Phys Anthropol, 157(3), 526-534.

Prasad, S.A., Rajasekhar, S.S.S.N. (2018). Morphometric analysis of talus and calcaneus. Surg Radiol Anat, 41(1), 9-24.

Radu, C., Szeredai, N. (2014). Anthropological analysis of a skeletal sample belonging to the sarmatian population inhabiting the territory at the East of the Pannonian Basin, JAHA, 80-85.

Simalcsik, A. (2018). Despre deformația craniană intenționată în comunitățile sarmatice. [Intentional cranial deformation in the sarmatic communities]. Acta Musei Tudovensis, 14, 91-106.

Singh, I. (1959). Squatting facets on the talus and tibia in Indians. J Anat, 93(4), 540-550.

Sjøvold, T. (1990). Estimation of stature from long bones utilizing the line of organic correlation. J Hum Evol, 5(5), 431-447.

Stirland, A.J. (1996). Femoral non-metric traits reconsidered. Anthropologie, 249-252.

Symons, A.L., Stritzel, F., Stamation, J. (1993). Anomalies associated with hypodontia of the permanent lateral incisor and second premolar. J Clin Pediatr Dent, 17, 109-109.

Timoc, C., Tănase, D., Ciobotaru, D.L., Flutur, A., Georgescu, A.V. (2017). Raport tehnic privind cercetarea arheologică preventivă de la Freidorf-Timișoara (Jud. Timiş), proiectul de construcție hală al firmei S.C. BarumTechnik S.R.L. [Technical report on preventive research from Timisoara - Freidorf (Timis county), construction project of S.C. Barum - Technik S.R.L.]. Muzeul Naţional al Banatului, Timişoara. 121 pp, Timişoara, România.

Tomaszewska, A., Kwiatkowska, B., Jankauskas, R. (2012). The localization of the supraorbital notch or foramen is crucial for headache and supraorbital neuralgia avoiding and treatment. Anat Rec, 295(9), 1494-1503.

Tomaszewska, A., Tomczyk, J., Kwiatkowska, B. (2013). Characterisation of the supraorbital foramen and notch as an exit route for the supraorbital nerve in populations from different climatic conditions. HOMO, 64(1), 58-70.

Tood, T. W. (1921). Age changes in the pubic bone. Am J Phys Anthropol, 1(4), 1-70.

Torok-Oance, R., Popa, S., Slejiuc, I. (2020). Rare association of anatomical variations of the atlas and the occipital in a case with cranial deformation. Anat Sci Int, 1-7.

Trinkaus, E. (1978). Bilateral asymmetry of human skeletal non-metric traits. Am J Phys Anthropol, 49(3), 315-318.

Tubbs, R. S., Shoja, M. M., Loukas, M. (Eds.). (2016). Bergman's comprehensive encyclopedia of human anatomic variation. John Wiley \& Sons, 1432 pp, New Jersey, SUA.

Voisin, J., Condemi S. (2014). Spy non-metric traits. Anthropologica et Prahistorica, 1-16.

White, T. D., Folkens, P.A. (2005). The human bone manual. Elsevier. 488 pp, Amsterdam, Holland.

White, T. D., Black, M.T., Folkens, P.A. (2011). Human osteology. Elsevier. 688 pp, Amsterdam, Holland. 


\section{Current Trends in Natural Sciences}

Vol. 9, Issue 18, pp. 20-31, 2020

https://doi.org/10.47068/ctns.2020.v9i18.003

Current Trends in Natural Sciences (on-line)

ISSN: 2284-953X

ISSN-L: 2284-9521
Current Trends in Natural Sciences (CD-Rom)

ISSN: 2284-9521

ISSN-L: 2284-9521

APPENDIX I. The list of epigenetic traits, where: $A=$ absent trait; $P=$ present; $C=$ complete; NR = not recordable; $L=$ lateral; $M=$ medial; $X=$ missing bone

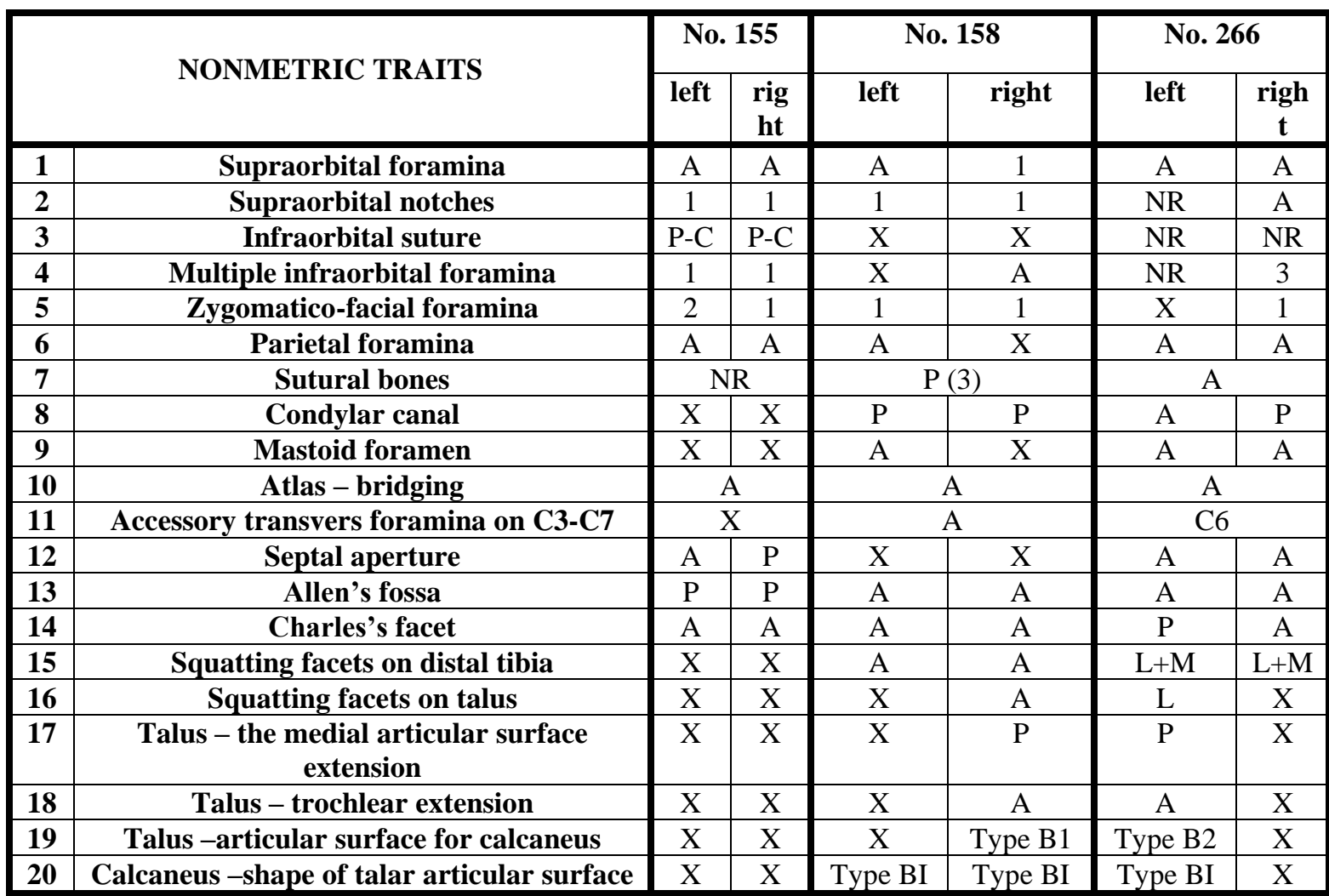


Current Trends in Natural Sciences

Vol. 9, Issue 18, pp. 20-31, 2020

https://doi.org/10.47068/ctns.2020.v9i18.003

Current Trends in Natural Sciences (on-line)

ISSN: 2284-953X

ISSN-L: 2284-9521
Current Trends in Natural Sciences (CD-Rom) ISSN: 2284-9521 ISSN-L: 2284-9521

APPENDIX II. The result of entheses scoring, where: $X=$ missing bone; $N R=$ Not recordable; $1 a=$ extremely low development; $1 b=$ low; $1 c=$ medium; $2=$ high; 3 very high

\begin{tabular}{|c|c|c|c|c|c|c|c|}
\hline \multirow{2}{*}{\multicolumn{2}{|c|}{ STUDIED AREA }} & \multicolumn{2}{|c|}{$\overline{M 155}$} & \multicolumn{2}{|c|}{ M158 } & \multicolumn{2}{|c|}{ M266 } \\
\hline & & \multirow{2}{*}{\begin{tabular}{|l|} 
left \\
NR \\
\end{tabular}} & \multirow{2}{*}{$\begin{array}{c}\text { right } \\
\mathrm{NR} \\
\end{array}$} & \multirow{2}{*}{$\begin{array}{c}\text { left } \\
1 b\end{array}$} & \multirow{2}{*}{$\frac{\text { right }}{1 \mathrm{c}}$} & \multirow{2}{*}{$\frac{\text { left }}{1 \mathrm{a}}$} & \multirow{2}{*}{$\frac{\text { righ }}{1 \mathrm{a}}$} \\
\hline 1 & Scapula-m. triceps brachii & & & & & & \\
\hline 2 & Clavicula- costoclavicular ligament & $1 \mathrm{a}$ & $1 \mathrm{a}$ & $1 \mathrm{~b}$ & $1 \mathrm{~b}$ & $1 \mathrm{c}$ & $1 \mathrm{a}$ \\
\hline 3 & Clavicula- conoid ligament & $\mathrm{X}$ & $1 b$ & 2 & $1 \mathrm{c}$ & $1 \mathrm{c}$ & 2 \\
\hline 4 & Clavicula- trapezoid ligament & $\mathrm{X}$ & $1 \mathrm{c}$ & $1 \mathrm{~b}$ & $1 \mathrm{c}$ & $1 \mathrm{~b}$ & $1 \mathrm{c}$ \\
\hline 5 & Clavicula- m. pectoralis major & $1 \mathrm{c}$ & $1 \mathrm{~b}$ & $1 \mathrm{~b}$ & $1 \mathrm{c}$ & $1 \mathrm{c}$ & 2 \\
\hline 6 & Clavicula- m. deltoideus & $\mathrm{X}$ & $1 \mathrm{c}$ & 2 & $1 \mathrm{c}$ & $1 \mathrm{c}$ & 2 \\
\hline 7 & Humerus- m. pectoralis major & $\mathrm{X}$ & $1 \mathrm{~b}$ & 2 & $1 \mathrm{c}$ & NR & NR \\
\hline 8 & Humerus- m. latissimus dorsi/teres major & $\mathrm{X}$ & $1 \mathrm{c}$ & $1 \mathrm{~b}$ & $1 \mathrm{~b}$ & NR & NR \\
\hline 9 & Humerus- $m$. deltoideus & NR & NR & $1 \mathrm{~b}$ & $1 \mathrm{~b}$ & $1 \mathrm{~b}$ & $1 \mathrm{a}$ \\
\hline 10 & Humerus- $m$. brachioradialis & NR & NR & NR & NR & NR & $1 \mathrm{c}$ \\
\hline 11 & Radius- m. biceps brachii & NR & NR & $1 \mathrm{~b}$ & $1 \mathrm{~b}$ & $1 \mathrm{c}$ & NR \\
\hline 12 & Radius- m.pronator teres & NR & NR & $1 \mathrm{a}$ & $1 \mathrm{~b}$ & $1 \mathrm{a}$ & $1 \mathrm{a}$ \\
\hline 13 & Radius- interosseous membrane & NR & NR & $1 \mathrm{a}$ & NR & NR & $1 \mathrm{a}$ \\
\hline 14 & Ulna- m.triceps brachii & $1 \mathrm{c}$ & $\mathrm{NR}$ & NR & $\mathrm{NR}$ & NR & NR \\
\hline 15 & Ulna- m.supinator & NR & 2 & $1 \mathrm{c}$ & $1 \mathrm{c}$ & $1 \mathrm{~b}$ & $1 \mathrm{c}$ \\
\hline 16 & Ulna- m.brachialis & $1 \mathrm{~b}$ & NR & $1 \mathrm{c}$ & $1 \mathrm{c}$ & $1 \mathrm{c}$ & $1 \mathrm{c}$ \\
\hline 17 & Femur-m.gluteus maximus & NR & $\mathrm{NR}$ & $1 \mathrm{c}$ & $1 \mathrm{a}$ & $1 \mathrm{a}$ & $1 \mathrm{a}$ \\
\hline 18 & Femur- m.vastus medialis & NR & NR & $1 \mathrm{c}$ & $1 \mathrm{c}$ & $1 \mathrm{a}$ & $1 \mathrm{a}$ \\
\hline 19 & Femur- m.iliopsoas & NR & NR & NR & NR & $1 \mathrm{~b}$ & $1 \mathrm{~b}$ \\
\hline 20 & Patella- quadriceps tendon & $\mathrm{X}$ & $X$ & $\mathrm{X}$ & $\mathrm{X}$ & $1 \mathrm{c}$ & $\mathrm{X}$ \\
\hline 21 & Tibia- quadriceps tendon & NR & NR & NR & NR & NR & $1 \mathrm{~b}$ \\
\hline 22 & Tibia-m.soleus & $1 \mathrm{c}$ & $1 \mathrm{c}$ & $1 \mathrm{a}$ & $1 \mathrm{a}$ & $1 \mathrm{~b}$ & $1 \mathrm{a}$ \\
\hline 23 & Calcaneus- Achilles tendon & $\mathrm{X}$ & $\mathrm{X}$ & NR & $\mathrm{NR}$ & $1 \mathrm{~b}$ & $\mathrm{NR}$ \\
\hline
\end{tabular}

